\title{
Penerapan Model Pembelajaran Kooperatif Tipe Team Assissted Individualization (T A I) Sebagai Upaya Meningkatkan Prestasi Belajar Matematika
}

\author{
Dewa Ayu Oka Naba*
}

SMP Negeri 1 Blahbatuh

\begin{abstract}
Abstrak
Penelitian ini dilaksanakan di SMP Negeri 1 Blahbatuh di Kelas IX F yang kemampuan siswanya untuk mata pelajaran Matematika masih rendah. Tujuan penulisan penelitian tindakan kelas ini adalah untuk mengetahui apakah prestasi belajar siswa dapat ditingkatkan dengan menerapkan langkah-langkah model pembelajaran Kooperatif Tipe Team Assissted Individualization (T A I). Metode pengumpulan datanya adalah tes prestasi belajar. Metode analisis datanya adalah deskriptif. Hasil yang diperoleh dari penelitian ini adalah prestasi belajar siswa dapat ditingkatkan dengan menerapkan langkah-langkah model pembelajaran Kooperatif Tipe Team Assissted Individualization (T A I). Ini terbukti dari hasil yang diperoleh pada awalnya 67,94 pada siklus I meningkat menjadi 72,56 dan pada Siklus II meningkat menjadi 80,51. Kesimpulan yang diperoleh dari penelitian ini adalah prestasi belajar siswa dapat ditingkatkan dengan menerapkan langkah-langkah model pembelajaran Kooperatif Tipe Team Assissted Individualization (T A I).
\end{abstract}

Kata Kunci:

Model Pembelajaran Kooperatif Tipe Team Assissted Individualization ( $T$ A I), Prestasi Belajar

\begin{abstract}
This research was carried out at SMP Negeri 1 Blahbatuh in Class IX F where students' abilities for mathematics were still low. The purpose of writing this class action research is to find out whether student achievement can be improved by applying the steps of the Cooperative Learning Model Team Assissted Individualization (T A I) type. The data collection method is a learning achievement test. The data analysis method is descriptive. The results obtained from this study are student achievement can be improved by applying the steps of the Cooperative Learning Model Team Assissted Individualization (T A I) type. This is evident from the results obtained initially 67.94 in the first cycle increased to 72.56 and in Cycle II increased to 80.51. The conclusion obtained from this study is that student learning achievement can be improved by applying the steps of the Team Assissted Individualization Type of Cooperative learning model (T A I).
\end{abstract}

Keywords:

Cooperative Learning Model Type Team

Assissted Individualization ( $T$ A

I), Learning

Achievement 


\section{PENDAHULUAN}

Pendidikan merupakan salah satu bidang yang mempunyai peranan besar dalam pembangunan di suatu negera selain bidang ekonomi, politik, keamanan, dan sebagainya. Maju mundurnya bangsa banyak ditentukan oleh maju mundurnya pendidikan, oleh karena itu pendidikan harus dilaksanakan sebaikbaiknya agar memperoleh hasil yang maksimal. Pendidikan di Indonesia masih tertinggal dari negara-negara lain, salah satu faktornya belum sadarnya masyarakat tentang pentingnya pendidikan dan dengan banyaknya siswa yang tidak melanjutkan ke jenjang pendidikan yang lebih tinggi, maka dari itu Pendidikan di Indonesia yang berakar pada kebudayaan bangsa berdasarkan Pancasila dan UndangUndang Dasar 1945 terus ditata, dikembangkan, dilengkapi berbagai ketentuan peraturan serta mengutamakan pemerataan dan peningkatan kualitas pendidikan. Upaya ini perlu didukung oleh sumber daya pendidikan secara bertahap disertai keterpaduan dan efisiensi pelaksanaannya sehingga mampu memenuhi tuntutan dan kebutuhan pembangunan di Indonesia. Tujuan pendidikan nasional ini akan tercapai apabila semua pihak ikut serta mendukung kemajuan pendidikan itu, baik oleh pemerintah, guru sebagai pendidik maupun masyarakat. Usaha yang dilakukan pemerintah dalam meningkatkan mutu pendidikan yaitu dengan mengeluarkan berbagai kebijakan dan mengambil langkah-langkah perbaikan seperti perbaikan kurikulum, pemerataan tenaga pendidikan, sertifikasi guru, pemberian dana bantuan operasional sekolah serta penerapan ide-ide baru untuk peningkatan mutu pendidikan termasuk mutu guru. Guru memberikan peranan penting didalam pendidikan terutama didalam kegiatan belajar mengajar, agar kegiatan belajar mengajar berhasil maka guru dituntut untuk menguasai dan memahami berbagai keterampilan yang dapat mendukung efektivitas dan efesiensi kegiatan belajar mengajar. Guru adalah salah satu komponen pendidikan yang sangat berperan dalam usaha pembentukan sumber daya manusia yang potensial di bidang pembangunan. Oleh karena itu, guru merupakan salah satu unsur kependidikan harus berperan serta secara aktif dalam menempatkan kedudukannya sebagai tenaga profesional. Pada diri guru terletak tanggung jawab untuk membawa siswa pada suatu kedewasaan atau taraf kematangan tertentu. Sardiman (2012:125) mengatakan bahwa guru tidak sematamata sebagai "pengajar" yang melakukan transfer of knowledge, tetapi juga sebagai "pendidik" yang melakukan transfer of values dan "pembimbing" yang memberikan pengarahan dan menuntun siswa dalam belajar" (Firmansyah, 2015).

Dalam pelaksanaan pembelajaran di sekolah usaha untuk meningkatkan prestasi belajar siswa banyak mengalami kendala dan hambatan.Lebih-lebih pada mata pelajaran Matematika yang menuntut begitu banyak pencapaian konsep sehingga mengakibatkan motivasi belajar kurang baik. Motivasi belajar dapat dipengaruhi oleh faktor internal yaitu kemampuan yang berasal dari siswa,yang meliputi kecerdasan, bakat, minat, motivasi dan emosi. Dan juga dipengaruhi oleh faktor eksternal berasal dari luar, meliputi lingkungan keluarga, sekolah, dan masyarakat.

Guru merupakan pihak yang berhubungan langsung dengan siswa. Sehingga dalam memberikan evaluasi diharapkan lebih akurat, objektif, dan mengoptimalkan pembelajaran. Masalah yang dihadapi misalnya masalah kepribadian guru dan kompetensi, kecakapan mengajar, yang antara lain mencakup ketepatan pemilihan metode pendekatan, motivasi, improvisasi, serta evaluasi. Disamping guru, orang tua juga merupakan pihak yang berperan utama dalam penanganan anak.Sebab interaksi anak dengan orang tua tetap lebih besar porsinya dibanding dengan interaksi guru dengan anak di sekolah. Orang tua harus mampu menciptakan kondisi dan menyediakan sarana yang menunjang proses belajar anak.

Menurut Aunurrahman, (2009: 176) keberhasilan proses pembelajaran merupakan muara dari seluruh aktivitas yang dilakukan guru dan siswa, artinya apapun bentuk kegiatan-kegiatan guru mulai dari merancang pembelajaran, memilih dan menentukan materi, pendekatan, strategi dan metode pembelajaran, memilih dan menggunakan teknik evaluasi semua disarankan untuk mencapai keberhasilan belajar siswa.

Minat dalam proses belajar mengajar merupakan salah satu faktor yang besar pengaruhnya terhadap prestasi belajar. Siswa yang minat belajarnya tinggi akan memperoleh prestasi belajar baik. Pentingnya motivasi belajar siswa terbentuk antara lain agar terjadi perubahan belajar ke arah lebih positif. Pandangan ini sesuai dengan pendapat Hawley yang dikemukakan Wardiana (2004: 149) bahwa siswa yang memiliki minat belajar tinggi akan melakukan kegiatan lebih banyak dan lebih cepat, dibandingkan dengan siswa yang kurang termotivasi dalam belajar. Prestasi yang diraih akan lebih baik apabila mempunyai minat belajar tinggi.

Aly (2004: 34) mengatakan bahwa prestasi belajar adalah hasil yang telah dicapai seseorang dalam usaha belajar yang dilakukan dalam periode tertentu. Sukmadinata (2008: 19) prestasi adalah hasil dari suatu kegiatan telah dikerjakan, diciptakan baik secara individual maupun kelompok. Ahmadi (2005: 52) menjelaskan bahwa prestasi belajar adalah hasil yang dicapai oleh seseorang setelah ia melakukan perubahan belajar, baik di sekolah maupun di luar sekolah. Djamarah (2006: 19) mengatakan prestasi 
adalah hasil dari suatu kegiatan yang telah dikerjakan, diciptakan baik secara individu maupun secara kelompok (Rusmiati, 2017).

Namun demikian, kenyataan yang terjadi di lapangan sangat jauh dari harapan kita semua. Prestasi belajar matematika siswa di SMP Negeri 1 Blahbatuh sangat jauh dari nilai KKM yang ditentukan untuk mata pelajaran ini yaitu 73. Nilai rata-rata siswa dan prosentase ketuntasan mata pelajaran matematika pada siswa kelas IX F semester I tahun ajaran 2018/2019 hanya 46,15\%.

Melihat kenyataan ini, peneliti dalam hal ini adalah guru di sekolah ini harus melakukan pembenahan strategi pembelajaran untuk memperbaiki prestasi belajar Matematika khususnya. Mata pelajaran Matematika adalah mata pelajaran untuk pengembangan intelektual sosial dan emosional siswa serta berperan sebagai kunci penentu menuju keberhasilan dalam mempelajari bidang-bidang yang lain. Untuk itu peneliti melaksanakan pembelajaran dengan penerapan langkah-langkah model pembelajaran Kooperatif Tipe Team Assissted Individualization (TAI). Dengan model pembelajaran ini peneliti sangat berharap prestasi belajar Matematika siswa dapat ditingkatkan.

Maka dari itu, pada penelitian ini mengambil judul tentang Penerapan Model Pembelajaran Kooperatif Tipe Team Assissted Individualization (T A I) Sebagai Upaya Meningkatkan Prestas Belajar Matematika Pada Siswa Kelas IX F Semester I SMP Negeri 1 Blahbatuh Tahun Pelajaran 2018/2019.

\section{METODE PENELITIAN}

Penelitian tindakan kelas (PTK) ini mengacu pada teori yang dikemukakan Stephen Kemmis dan Robin McTaggart (dalam Agung, 2005:91). Penelitian tindakan kelas dilaksanakan dalam bentuk siklus berulang dan berkelanjutan yang di dalamnya terdapat empat tahapan utama kegiatan. Keempat tahapan utama tersebut yaitu perencanaan (planning), tindakan (action), observasi dan evaluasi (observation and evaluation), refleksi (reflecting) (Arikunto, dkk, 2007: 104). Siklus tersebut dapat digambarkan dalam model seperti gambar berikut.

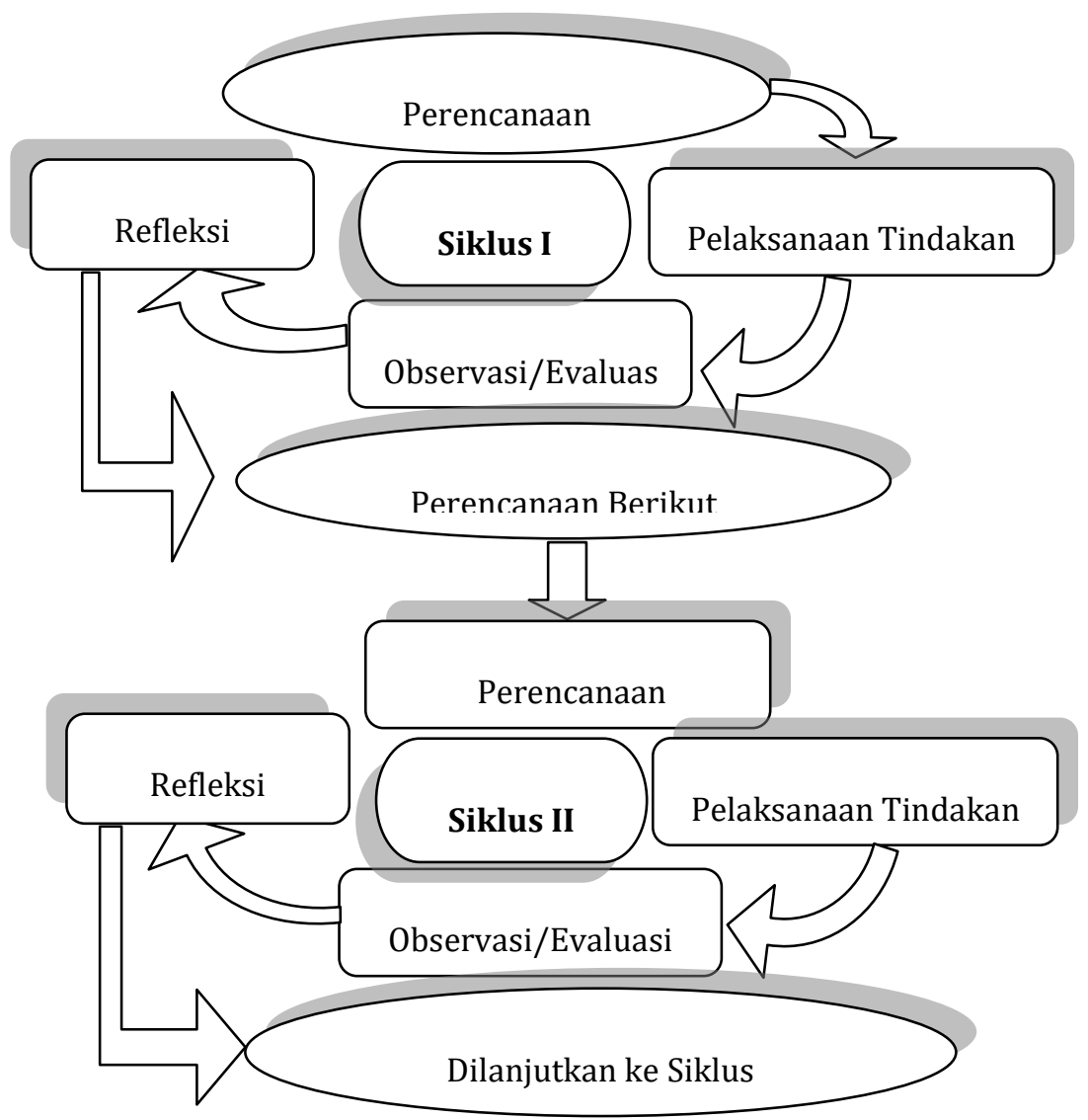

Gambar 1. Model Penelitian Tindakan Kelas (PTK) 
Prosedur:

Tindakan daur I dilakukan definisi masalah dilanjutkan dengan pelaksanaan di lapangan, dirumuskan hipotesisnya, dikembangkan hipotesis tersebut, diimplementasikan, dievauasi dari hasil yang didapat dan evaluasi diterapkan. Langkah-langkah pada daur II atau siklus II sama dengan yang di siklus I yaitu dimulai dengan adanya suatu permasalahan yang baru, didefinisikan masalahnya, dibuat hipotesisnya direvisi, selanjutnya dialkukan implementasi di lapangan, dievaluasi, kemudian hasil yang didapat merupakan penerapanbaru apabila masih adalah masalah.

Pengumpulan data dalam penelitian ini menggunakan tes prestasi belajar. Tes prestasi belajar berupa tes soal isian maupaun esay. Setelah data dalam penelitian ini terkumpul selanjutnya dilakukan analisis data. Dalam menganalisis data digunakan teknik analisis statistik deskriptif kuantitatif. Agung (1997) mengemukakan metode analisis deskriptif kuantitatif merupakan pengolahan data yang dilakukan dengan jalan penyusunan secara sistematis dalam bentuk angka-angka dan atau persentase mengenai keadaan suatu objek yang diteliti sehingga diperoleh kesimpulan umum. Untuk menghitung nilai rata-rata (Mean) digunakan rumus sebagai berikut.

$$
\mathrm{M}=\frac{\sum \mathrm{X}}{\mathrm{N}} \text { atau } \mathrm{M}=\frac{\sum \mathrm{FX}}{\mathrm{N}}
$$

Keterangan:

$$
\begin{aligned}
& \mathrm{M}(\text { mean })=\text { Skor rata-rata } \\
& \begin{array}{ll}
\sum \mathrm{X} & =\text { Jumlah skor perolehan } \\
\sum_{\mathrm{FX}} & =\text { Jumlah Frekuensi kali skor } \\
\mathrm{N} & =\text { Jumlah siswa }
\end{array}
\end{aligned}
$$

Untuk menentukan tingkat prestasi belajar siswa, terlebih dahulu dihitung rata-rata persen (M\%) dengan rumus:

$$
\mathrm{M} \%=\frac{M}{S M I} \times 100 \%
$$

Selanjutnya, rata-rata persen dibandingkan dengan Pedoman Konversi Skala Lima sebagai berikut.

Tabel 1. Pedoman Konversi Skala Lima

\begin{tabular}{ll}
\hline Persentase (\%) & Kriteria \\
\hline $90-100$ & Sangat Baik \\
$75-89$ & Baik \\
$65-74$ & Cukup \\
$40-64$ & Kurang \\
$0-39$ & Sangat Kurang \\
\hline
\end{tabular}

Indikator keberhasilan penelitian yang diusulkan dalam penelitian ini pada siklus I dan II mencapai nilai rata-rata 75,00 dengan ketuntasan belajar 85\%. dengan KKM yang ditetapkan untuk mata pelarajan Bahasa Indonesia pada SMA Negeri 1 Blahbatuh adalah 73.

\section{ANALISIS DAN PEMBAHASAN}

Penelitian Prestasi belajar Matematika sama dengan prestasi belajar bidang studi yang lain merupakan hasil dari proses belajar siswa dan sebagaimana biasa dilaporkan pada wali kelas, murid dan orang tua siswa setiap akhir semester atau akhir tahun ajaran. Djamarah (1994:23) mendefinisikan prestasi belajar sebagai hasil yang diperoleh berupa kesan-kesan yang mengakibatkan perubahan dalam diri individu sebagai hasil dari aktivitas dalam belajar. Kalau perubahan tingkah laku adalah tujuan yang mau dicapai dari aktivitas belajar, maka perubahan tingkah laku itulah salah satu indikator yang dijadikan pedoman untuk mengetahui kemajuan individu dalam segala hal yang diperolehnya di sekolah. Dengan kata lain prestasi belajar merupakan kemampuan-kemampuan yang dimiliki oleh siswa sebagai akibat perbuatan belajar atau setelah menerima pengalaman belajar yang dapat dikatagorikan menjadi tiga ranah, yakni ranah kognitif, afektif, dan psikomotor.

Prestasi belajar Matematika siswa dapat ditingkatkan dengan menerapkan model pembelajaran kooperatif tipe TAI. Suyitno (2002: 9) memberi penjelasan bahwa model pembelajaran kooperatif tipe TAI merupakan model pembelajaran yang membentuk kelompok kecil yang heterogen dengan latar belakang 
cara berpikir yang berbeda untuk saling membantu terhadap siswa yang lain yang membutuhkan bantuan. Dalam model ini diterapkan bimbingan antar teman yaitu siswa yang pandai bertanggung jawab terhadap siswa yang lemah.Disamping itu dapat menumbuhkan partisipasi siswa dalam kelompok kecil. Siswa yang pandai dapat mengembangkan kemampuan dan keterampilannya, sedangkan siswa yang lemah dapat terbantuk menyelesaikan permasalahan yang dihadapi. Selanjutnya dijelaskan bahwa model pembelajaran tipe TAI memiliki komponen, yaitu: a) Teams, yaitu pembentuk kelompok heterogen yang terdiri atas 4-6 siswa. b) Placement test, yaitu pemberian pre-tes kepada siswa atau melihat rata-rata nilai harian siswa agar guru mengetahui kelemahan siswa dalam bidang tertentu. c) Student creative, yaitu melaksanakan tugas dalam suatu kelompok dengan menciptakan situasi dimana keberhasilan individu ditentukan atau dipengaruhi oleh keberhasilan kelompoknya. d) Team study, yaitu tahapan tindakan belajar yang harus dilakukan oleh kelompok dan guru memberi bantuan secara individual kepada siswa yang membutuhkan. e) Team scores and team recognation, yaitu pemberian skor terhadap hasil kerja kelompok dan memberikan kriteria penghargaan terhadap kelompok yang berhasil secara cemerlang dan kelompok yang dipandang kurang berhasil dalam menyelesaikan tugas. f) Teaching group, yaitu pemberian materi secara singkat dari guru menjelang pemberian tugas kelompok. g) Fact test, yaitu pelaksaan tes-tes kecil berdasarkan fakta yang diperoleh siswa. h) Whole class units, yaitu pemberian materi oleh guru kembali di akhir waktu pembelajaran dengan strategi pemecahan masalah.

Pada penelitian ini hasil siklus awal diperolehan nilai rata rata kelas prestasi belajar matematika masih sangat rendah, yaitu dengan perolehan skor nilai secara klasikal yaitu 2650 dan rata rata kelas 67,94 dimana siswa yang mencapai persentase ketuntasan belajar 46,15\%, dan yang tidak mencapai ketuntasan adalah 53,84\%, dengan tuntutan KKM untuk mata pelajaran matematika kelas IX F SMP Negeri 1 Blahbatuh adalah dengan nilai 73.

Selanjutnya berdasarkan penelitian yang telah dilakukan dengan menerapkan model pembelajaran tipe TAI didapatkan hasil pada siklus I rata-rata nilai 72,56 dari jumlah nilai secara klasikal 2830 seluruh siswa di kelas IX F, dan prosentase ketuntasan belajarnya adalah 71,79\%, yang tidak tuntas adalah 28,20\%. Hasil ini belum maksimal, karena belum mecapai indikator keberhasilan penelitian yang mencanangkan dengan minimal prosentase ketuntasan belajar 85\%.

Dengan tindakan yang sangat maksimal dan pelaksanaan yang betul-betul mengikuti kebenaran teori sesuai dengan model pembelajaran kooperatif TAI dalam pembelajaran matematika di kelas IX F SMP Negeri 1 Blahbatuh, dimana hasil yang diperoleh pada siklus II ini ternyata prestasi belajar Matematika meningkat secara signifikan dengan nilai rata-rata 80,51 dan ketuntasan belajarnya adalah 97,43\%. Dari keseluruhan jumlah siswa yaitu 39 orang siswa 38 orang siswa telah mampu melampaui nilai KKM yaitu 73. Semua hasil yang diperoleh dari awal, siklus I dan siklus II dipaparkan dalam bentuk tabel dan gambar seperti berikut.

Tabel 2. Tabel Data Prestasi Belajar Siswa kelas IX F SMP Negeri 1 Blahbatuh

\begin{tabular}{llll}
\hline DATA & AWAL & SIKLUS I & SIKLUS II \\
\hline Skor Rata Kelas & 2650 & 2830 & 3140 \\
Rata Rata Kelas & 67,94 & 72,56 & 80,51 \\
Presentase Ketuntasam & $46,15 \%$ & 71,79 & $97,43 \%$ \\
\hline
\end{tabular}

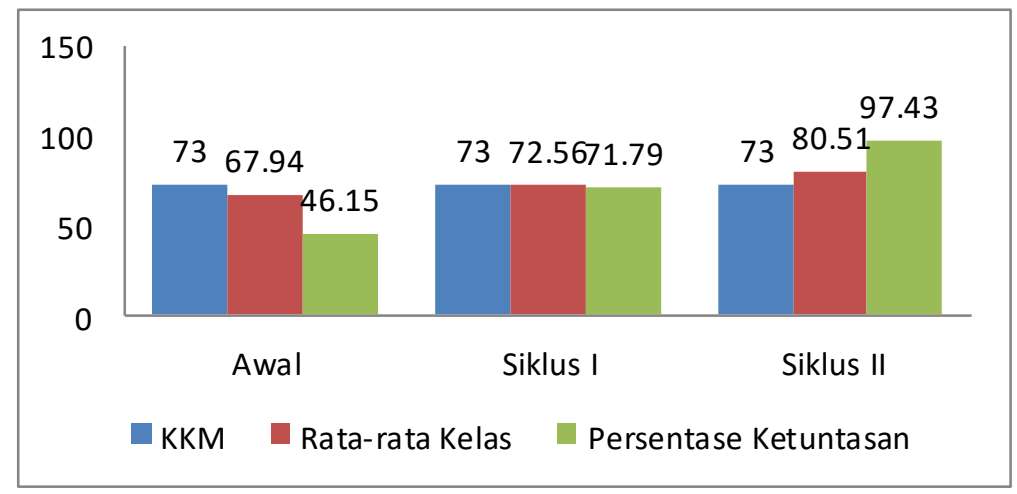

Gambar 2. Grafik Histogram Prestasi Belajar matematika siswa kelas IX F semester I tahun pelajaran 2018/2019 SMP Negeri 1 Blahbatuh 
Hasil penelitian ini sejalan dengan hasil penelitian yang dilakukan oleh Yuliantari pada tahun 2016 dengan judul Implementasi Model Pembelajaran Kooperatif Tipe TAI (Team Assisted Individualization) untuk Meningkatkan Aktivitas Dan Hasil Belajar Siswa pada Mata Pelajaran Kewirausahaan Kelas X SMK N 1 Sukasada, Tahun Ajaran 2015/2016. Hasil penelitian menunjukkan bahwa, (1) implementasi model pembelajaran kooperatif tipe TAI dapat meningkatkan aktivitas belajar siswa yang ditunjukkan dengan rata-rata skor aktivitas belajar siklus I sebesar 33,5 dengan kategori cukup aktif selanjutnya meningkat menjadi 39,25 dengan kategori aktif pada siklus II. (2) Implementasi model pembelajaran kooperatif tipe TAI dapat meningkatkan hasil belajar siswa yang ditunjukkan dengan rata-rata skor hasil belajar siklus I sebesar 77,12 dengan kategori cukup selanjutnya meningkat menjadi 89,35 dengan kategori sangat baik pada siklus II.

Selanjutnya penelitian yang dilakukan oleh Ariestika, dkk pada tahun 2015 dengan judul Penerapan Model Pembelajaran Kooperatif Tipe Team Assisted Individualization (TAI) Berbantuan Lembar Kerja Siswa (LKS) Terstruktur Untuk Meningkatkan Hasil Belajar Matematika. Berdasarkan analisis data dapat disimpulkan bahwa penerapan model pembelajaran kooperatif tipe Team Assisted Individualization (TAI) berbantuan Lembar Kerja Siswa (LKS) terstruktur dapat meningkatkan hasil belajar Matematika siswa kelas V SD Negeri 1 Tajun. Hal ini dapat dilihat dari rata-rata kelas, daya serap, dan ketuntasan belajar klasikal. Sebelum tindakan, rata-rata ketuntasan hasil belajar belum memenuhi kreteria yang telah ditetapkan. Pada skor awal, rata-rata hasil belajar siswa mencapai 61 pada siklus I mencapai 69 berarti mengalami peningkatan sebesar 8 poin pada siklus I, dan rata-rata hasil belajar siswa mencapai 76 pada siklus II berarti terjadi peningkatan sebesar 7 poin dari siklus I ke siklus II. Ketuntasan belajar siswa terhadap materi pelajaran pada skor awal mencapai $52 \%$, pada siklus I mencapai $85 \%$ terjadi peningkatan sebesar 33\% pada siklus I, dan ketuntasan belajar siswa terhadap materi pelajaran pada siklus II mencapai 100\% sehingga terjadi peningkatan sebesar 15\% dari siklus I ke siklus II.

\section{KESIMPULAN}

Berdasarkan penelitian yang telah dilakukan dapat disimpulkan bahwa: penerapan model pembelajaran kooperatif tipe Team Assissted Individualization (T A I) secara efektif dapat meningkatkan prestas belajar matematika pada siswa kelas IX F semester I SMP Negeri 1 Blahbatuh tahun pelajaran 2018/2019.

Dari simpulan tersebut dapat disampaikan beberapa saran yakni: Siswa diharapkan untuk selalu bersemangat dan rajin belajar agar cita-cita yang diinginkan dapat tercapai secara optimal. Guru disarankan untuk selalu menggunakan pembelajaran yang bervariasi dalam mengajar, sehingga siswa tidak merasa jenuh dalam belajar. Sekolah disarankan untuk menyiapkan sarana dan prasarana pembelajaran sesuai dengan kebutuhan pembelajaran di sekolah.

\section{DAFTAR PUSTAKA}

Adnyani, Nyoman. 2002. Kelemahan-kelemahan Peneriman Siswa SMP yang Beracuan pada NUAN. Makalah yang Disampaikan dalam Seminar Ilmiah Universitas Mahasaraswati, Septermber 2003.

Agung, A.A. Gede. 1997. Metodologi Penelitian Pendidikan. Singaraja: IKIP Negeri Singaraja.

Agung, A.A. Gede. 2005. Metodologi Penelitian Pendidikan. Singaraja: STKIP Singaraja.

Ali, MS. 2002. Hasil Belajar Fisika Ditinjau dari Beberapa Faktor Psikologis. Disertasi.IKIP. Jakarta.

Alien, Deborah .et-al 1996.The Power of Problem Based Learning in Teaching Introductory Science Courses. Jossey-Boss Publisher.

Amien, Moh. 1996. Perkembangan Intelektual Siswa SMP. Jurnal Ilmu Pendidikan. Jilid 3 No. 4. Jakarta: LTPTK dan ISP.

Anastasi, Anne. 1976. Psychological Testing. Fifth Edition. New York: Macmillan Publishing Co., Inc.

Anom.2000. Profesionalisme Guru Fisika dalam Menghadapi Tantangan Era Global.Makalah.Disampaikan pada Seminar dalam Rangka HUT ke 36 Jurusan Fisika STKIP Singaraja pada 1 hari Minggu 5 Nopember 2000. 
Ardana, Nengah. 1999. Hubungan antara Motivasi Belajar dan Pola Pemberian Tugas dengan Prestasi Belajar Bidang Studi Fisika pada Siswa SMP Negeri 1 Denpasar. Skripsi.IKIP Mahasaraswati Tabanan.

Arief Furchan. 2004. Pengantar Penelitian dalam Pendidikan. Pustaka Belajar: Yogyakarta.

Ariestika, dkk. 2015. Penerapan Model Pembelajaran Kooperatif Tipe Team Assisted Individualization (TAI) Berbantuan Lembar Kerja Siswa (LKS) Terstruktur Untuk Meningkatkan Hasil Belajar Matematika. E-Journal PGSD Universitas Pendidikan Ganesha Jurusan PGSD Vol: 3 No: 1 Tahun: 2015.

Firmansyah, Dani. 2015. Engaruh Strategi Pembelajaran Dan Minat Belajar Terhadap Hasil Belajar Matematika . Jurnal Pendidikan Unsika Volume 3 Nomor 1, Maret 2015.

Rusmiati. 2017. Pengaruh Minat Belajar Terhadap Prestasi Belajar Bidang Studi Ekonomi Siswa Ma Al Fattah Sumbermulyo . UTILITY : Jurnal ilmiah pendidikan eknomi Volume 1, No. 1, Februari 2017: Page 21-36

Suharsimi, Arikunto, dkk. 2007. Penelitian Tindakan Kelas. Jakarta. Bumi Aksara.

Yuliantari, Ni Luh Putu. 2016. Implementasi Model Pembelajaran Kooperatif Tipe TAI (Team Assisted Individualization) untuk Meningkatkan Aktivitas Dan Hasil Belajar Siswa pada Mata Pelajaran Kewirausahaan Kelas X SMK N 1 Sukasada, Tahun Ajaran 2015/2016. Jurnal Program Studi Pendidikan Ekonomi (JPPE) Volume: 7 Nomor: 2 Tahun: 2016. 